\title{
Geochemical and mineralogical characterization of phosphatic crusts developed on the basement carbonatites of Sri Lanka: towards a better understanding of the weathering process
}

G.T.D. Chandrakumara, N.W.B. Balasooriya*, M.M.M.G.P.G. Mantilaka, B.G. Lottermorser and H.M.T.G.A. Pitawala

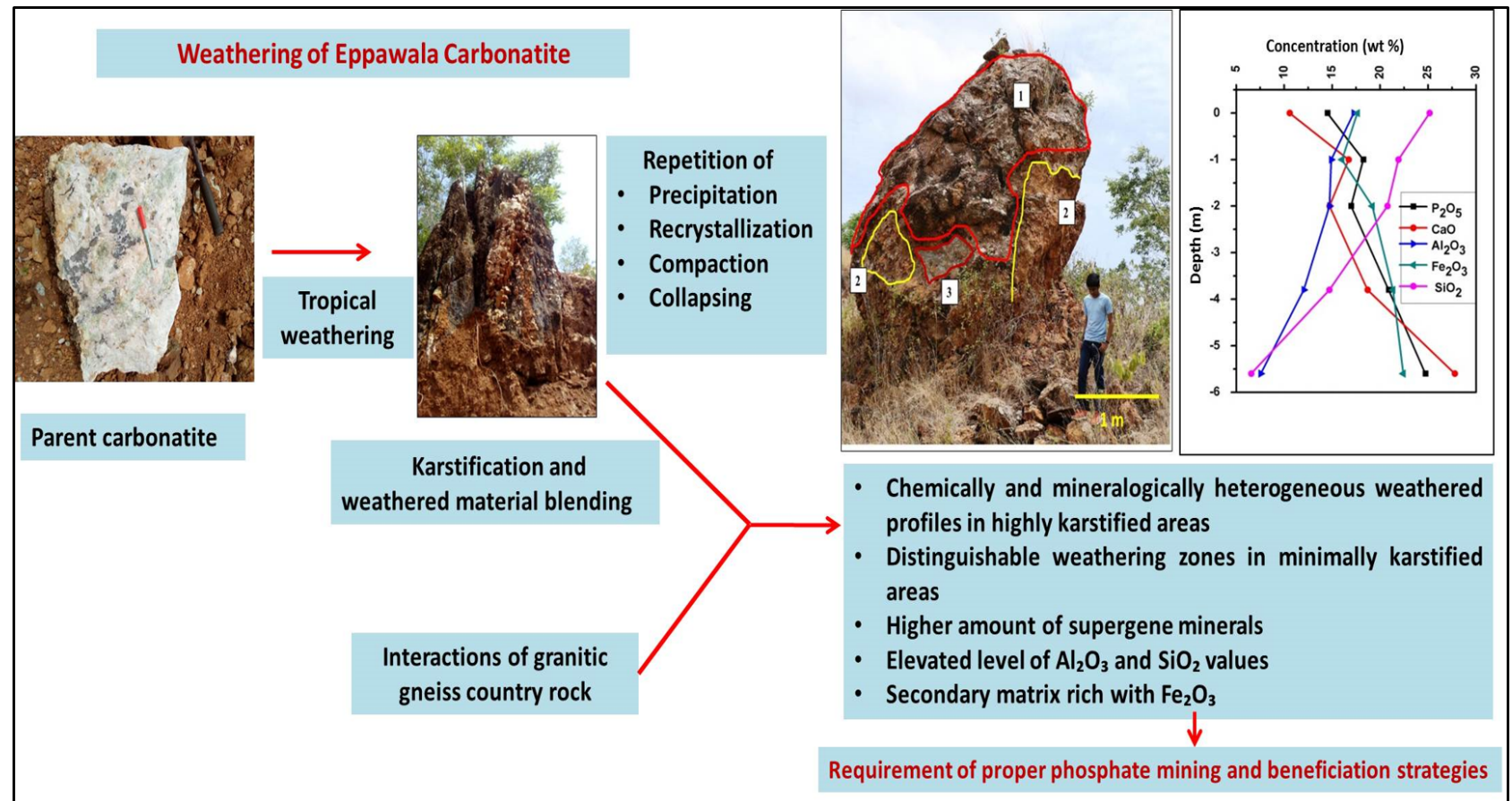

\section{Highlights}

- The phosphatic weathering crusts in minimally karstified areas at the Eppawala Southern quarry exhibit distinguishable weathering zonations.

- Various supergene phases accommodating REEs provides the hue of valuable industrial potential from the ore other than phosphate.

- The granitic country rock has interacted with the carbonatite during the weathering process.

- The phosphate matrix is highly enriched with elements which are toxic to plants and must be removed prior to the application as fertilizers. 
RESEARCH ARTICLE

\title{
Geochemical and mineralogical characterization of phosphatic crusts developed on the basement carbonatites of Sri Lanka: towards a better understanding of the weathering process
}

\author{
G.T.D. Chandrakumara ${ }^{1,2}$, N.W.B. Balasooriya ${ }^{1,2, *}$, M.M.M.G.P.G. Mantilaka ${ }^{1}$, B.G. Lottermorser ${ }^{3}$ and \\ H.M.T.G.A. Pitawala ${ }^{1,2}$ \\ ${ }^{1}$ Postgraduate Institute of Science, University of Peradeniya, Peradeniya, Sri Lanka. \\ ${ }^{2}$ Department of Geology, Faculty of Science, University of Peradeniya, Peradeniya, Sri Lanka. \\ ${ }^{3}$ Institute of Mineral Resources Engineering, RWTH Aachen University, Aachen, Germany.
}

Received: 24/06/2021; Accepted: 03/10/2021

\begin{abstract}
The diversity and complexity of basement rocks at Eppawala are accompanied by complicated matrices of phosphate deposits. Detailed field, geochemical and mineralogical studies were carried out on phosphatic weathering crusts developed on carbonatite occurrences to elucidate the weathering process and to explore mineralization of possible economic minerals. The presence of markedly distinguished weathering horizons at the Eppawala southern quarry (ES) site provided an advantage for studying the sequence of alteration and weathering processes occurred on the parent bodies. Leaching of carbonate minerals in the early stages had resulted in the alteration of primary apatite. Under diverse conditions, several generations of supergene phosphate minerals have formed. All major and trace elements in the profile are mobile and displaced due to weathering of the principal minerals, with the exception of $\mathrm{Mg}, \mathrm{Sr}, \mathrm{Na}$ and $\mathrm{Ba}$. The lower leached zone and higher-saprolitic layers are enriched with Rare Earth Elements (REEs) due to the presence of a high amount of secondary phosphates, such as crandallite, gorceixite, florencite and goyazite. Anomalies of REEs in upper lateritic layers are inherited by the presence of smectite group clay minerals. The presence of a high amount of silicate minerals and high $\mathrm{SiO}_{2}$ content indicates the interactions between carbonatites and surrounding granitic rocks during the weathering process. Moreover, geochemical results confirm that the several phosphate matrices are highly enriched with $\mathrm{Fe}_{2} \mathrm{O}_{3}$. Therefore, iron bearing phases must be removed during the production of phosphate fertilizer. Understanding of detailed mineralogical and geochemical variations of exposed phosphate orebodies along with the weathering profiles at Eppawala is critical to mining processes and beneficial for the production of phosphate fertilizer and REEs.
\end{abstract}

Keywords: Carbonatites; phosphates deposits; supergene mineralization; weathering.

\section{INTRODUCTION}

\section{Weathering of carbonatite}

Carbonatites are a type of igneous rock made up of more than $50 \%$ carbonate minerals, mainly calcite and dolomite (Le Bas, 1981; Mitchell, 2005). Because of the high dissolution rate of carbonate minerals in the tropical environment, these rocks are prone to weathering while exhibiting similarities with the weathering and karstification of marbles and limestones (Lottermoser, 1990; Witt et al., 2019). Based on the climatic conditions, geochemistry and mineralogy of parent igneous rock, the weathering process of carbonatite creates a weathered profile consisting of numerous secondary products ( Roseiro et al., 2020; Broom-Fendley et al., 2021). Weathered ores derived from carbonatites are great sources of nutrient-rich and economically valuable minerals (Walter et al., 1995; Chen et al., 2017; Witt et al., 2019; Jones et al., 2020). Hence, studying the weathering process of such a deposit is crucial when the weathered ore is evaluated for economic exploitation.

Many researchers have extensively studied the weathering process of carbonatite with the aid of various exposures distributed worldwide, such as Mt. Weld carbonatite laterite, Australia (Lottermoser, 1990); Jaquia carbonatite, Brazil (Walter et al., 1995); Lushe carbonatite complex, Democratic Republic of Congo (Nasraoui et al., 2000), and Matongo carbonatites, Burundi (Decree et al., 2016). In contrast to most hard rock types, carbonatites do not develop distinguishable sequential zonations in weathered profiles as a consequence of weathered material blending during the development of the karst environment (Hewawasam, 2013).

Carbonatite occurrences have been reported in the Eppawala and Kavisigamuwa areas in Sri Lanka, and numerous studies have been conducted to clarify the weathering patterns (Tazaki et al., 1987; Dahanayake and Subasinghe, 1989a; Dahanayake and Subasinghe, 1989b; Dahanayake and Subasinghe, 1991; Hewawasam, 2013). The literature reveals the development of phosphate ore under the influence of karstic environmental processes and the mineralization of multiple generations of secondary phosphates (Dahanayake and Subasinghe, 1989b; Yatawara, Pitawala and Balasooriya, 2020). However, all the above-mentioned studies were conducted on complex, thick weathering profiles developed under karstic conditions in which all the weathering zones could not be clearly distinguished. Such highly diverse profiles do not 
provide reliable evidence about the weathering processes of parent rocks. As a consequence, elucidating the carbonatite weathering using Eppawala main (EM) quarry is deemed to be complicated since it comprises thick weathered profiles overlying the basement carbonatite rock located more than $60 \mathrm{~m}$ below current mining levels. In contrast to the EM site, the weathering profiles developed at the Eppawala Southern (ES) site comprise areas minimally affected by karstification and exhibit distinctive zonations starting from the parent carbonatite to lateritic soil. The profile selected for this study is relatively low in thickness and visually minimally disturbed. Moreover, the granitic country rocks are clearly visible in the vicinity of the ES. Hence, the weathering profiles developed at ES quarry with less complexity were selected for the examination of the weathering process of carbonatites associated with high grade metamorphic rocks.

Almost all the scientific work conducted on the weathering of Eppawala phosphate ores was established before two to three decades. Owing to the higher demand for rock phosphate fertilizers, mining activities have been expanded further by excavating new quarry sites. For this reason, a timely requirement arises to evaluate the geochemical and mineralogical conditions of recent mining sites with newly exposed layers that could have developed from different basement geological conditions with respect to the site selected for previous studies. The paucity of such data can directly affect the quality of products manufactured from phosphate ore. Furthermore, the majority of the previous studies are limited to the major elements except the studies done by Tazaki et al. in 1987 on the phosphate ore. Phosphate deposits derived from the weathering of carbonatite may contain valuable minerals accommodating various uncommon metallic elements. Despite the previous studies focused only on phosphate ore bodies to be used as fertilizer, the other potential mineralizations have not been focused on. The weathering products of carbonatite bodies found in the world are significant sources of REEs, $\mathrm{Nb}, \mathrm{U}$, $\mathrm{Pb}, \mathrm{Sr}$ and $\mathrm{Ba}$ (Chakhmouradian et al., 2015; Roseiro et al., 2020; Xue et al., 2020; Zheng et al., 2020) which can be used as raw material for several industries related to hightech applications. Such geochemical aspects have not been touched by the previous researchers which are yet to be explored. For this reason, the findings of this study will be advantageous for the mineral industry.

Therefore, the main goal of this work is to better understand the weathering process of carbonatites in a tropical to semi-arid environment based on field observations as well as mineralogical and geochemical characteristics of recently exposed profiles. In addition, the current study intends to evaluate the quality of fertilizer that can be produced from heavily weathered zones where large primary apatite grains are uncommon, and to understand mineralization of economically important secondary minerals.

\section{Geological setting of Sri Lanka}

The crystalline basement of Sri Lanka has been subdivided into four major units, namely, Highland Complex (HC), Wanni Complex (WC), Vijayan Complex (VC) and Kadugannawa Complex (KC) based on the lithology, age and deformational features [Figure 1(a)]. Carbonatite occurrences are found in only WC. (a)

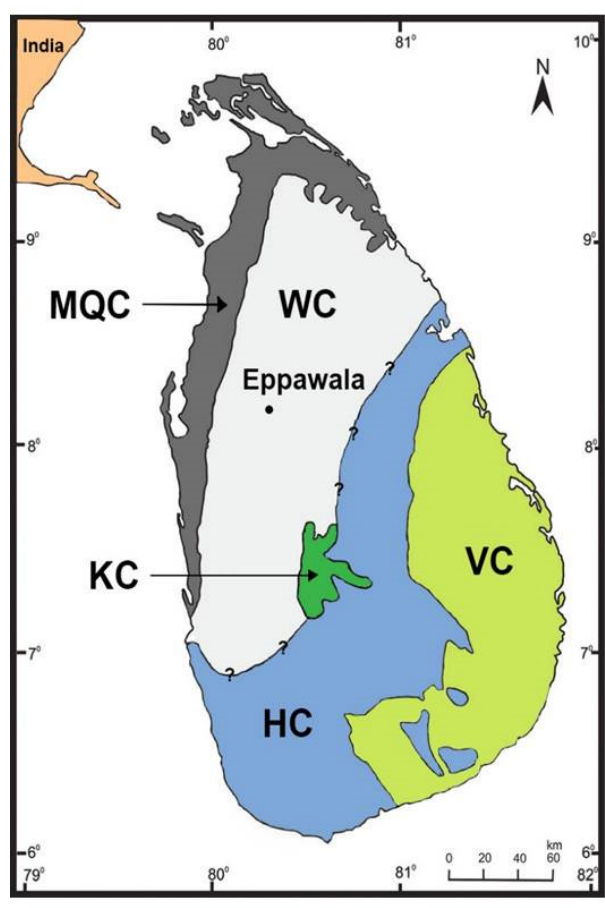

(b)

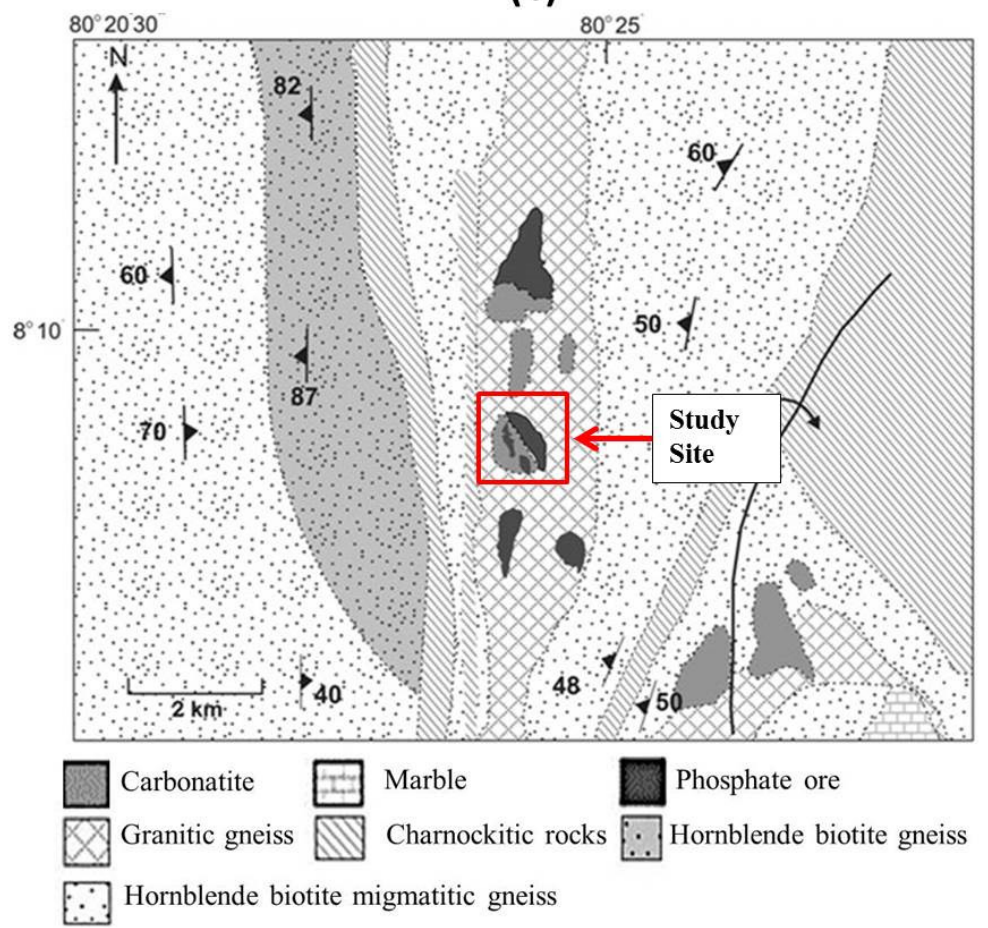

Figure 1: (a) The map showing general geology of Sri Lanka (Cooray, 1994) and the location of carbonatite occurrences at Eppawala (MQC: Miocene to Quaternary cover; WC: Wanni Complex; KC: Kadugannawa Complex; HC: Highland Complex; VC: Vijayan Complex) (b) The geological setting of the study area (Pitawala and Lottermoser, 2012). 


\section{Eppawala carbonatite occurrences}

\section{General geology of Eppawala area}

Carbonatite exposures in the Eppawala area belonging to Anuradhapura district, Sri Lanka, were discovered by the Geological Survey Department in 1971 [Figure 1(a)]. The geological setting of the Eppawala carbonatite was described for the first time by Jayawardena (1976), and further studied by numerous researchers (Pitawala et al., 2003; Manthilake et al., 2008; Pitawala and Lottermoser, 2012). As per the $\mathrm{Rb}-\mathrm{Sr}$ and $\mathrm{Sm}-\mathrm{Nd}$ isotopic data, the most possible intrusion age of the carbonatite occurrences was proposed as $550 \mathrm{Ma}$, during the late Neoproterozoic period after the high-grade metamorphism (Weerakoon et al., 2001). The carbonatite bodies are surrounded by Precambrian rocks which have been metamorphosed under upper-amphibolite to granulite facies [Cooray, 1994; Figure 1(b)].

Detailed studies have been carried out to evaluate the mineralogy and petrology of the Eppawala parent carbonatites (Manthilake et al., 2008; Pitawala and Lottermoser, 2012; Madugalla et al., 2017). The parent carbonatites are composed mainly of calcite (70\%), dolomite (10-20\%) and apatite, together with minor occurrences of magnetite, ilmenite and several silicate minerals. Spinel, rutile and monazite are the common accessory minerals.

\section{Climate and morphological condition of Eppawala area}

The study area belongs to the dry zone of the island where the mean annual rainfall is less than $1500 \mathrm{~mm}$, the average annual evaporation is $1400 \mathrm{~mm}$, and the average annual temperature is reported as $33{ }^{\circ} \mathrm{C}$ (Jayawardana et al., 2010). The groundwater table lies at a deeper level than the ground surface. The groundwater level shows higher fluctuations by moving upward as a result of high precipitation during the wet season while dropping due to evaporation and transpiration during the dry season. The terrain morphology of the area is almost flat. Additionally, the development of phosphate hillocks can be observed in areas with carbonatite occurrences.

\section{Eppawala southern quarry site}

The elongated hillock located $1 \mathrm{~km}$ away from the southern bank of the Yoda Ela stream was referred to as the ES quarry (Figure 2). Apatite-rich phosphate exposures at the ES site cover an area about $0.4 \mathrm{~km}^{2}$. The basement carbonatite rocks have been exposed in most of the excavated areas, while part of the quarry site has been abandoned after reaching the parent rock. Compared to the EM quarry, a thin weathering cover (approximately 10-20 m) overlies the basement rocks. The site is an active mining quarry located close to the contact zone of the country rocks, which have been recently exposed due to opencast mining activities. Exposed carbonatites in the basement are characterized by the formation of numerous cavities caused by the leaching of carbonate minerals, as well as the deposition of weathering-resistant minerals in such cavities. Primary minerals, such as apatite and iron oxide minerals, are generally incorporated in the secondary phosphate matrix in the profiles. Where the karstic influence is low, welldefined weathering horizons are present due to the shorter profile thickness. A combination of textural, structural, and mineralogical characteristics can be used to demarcate the weathering horizons easily.

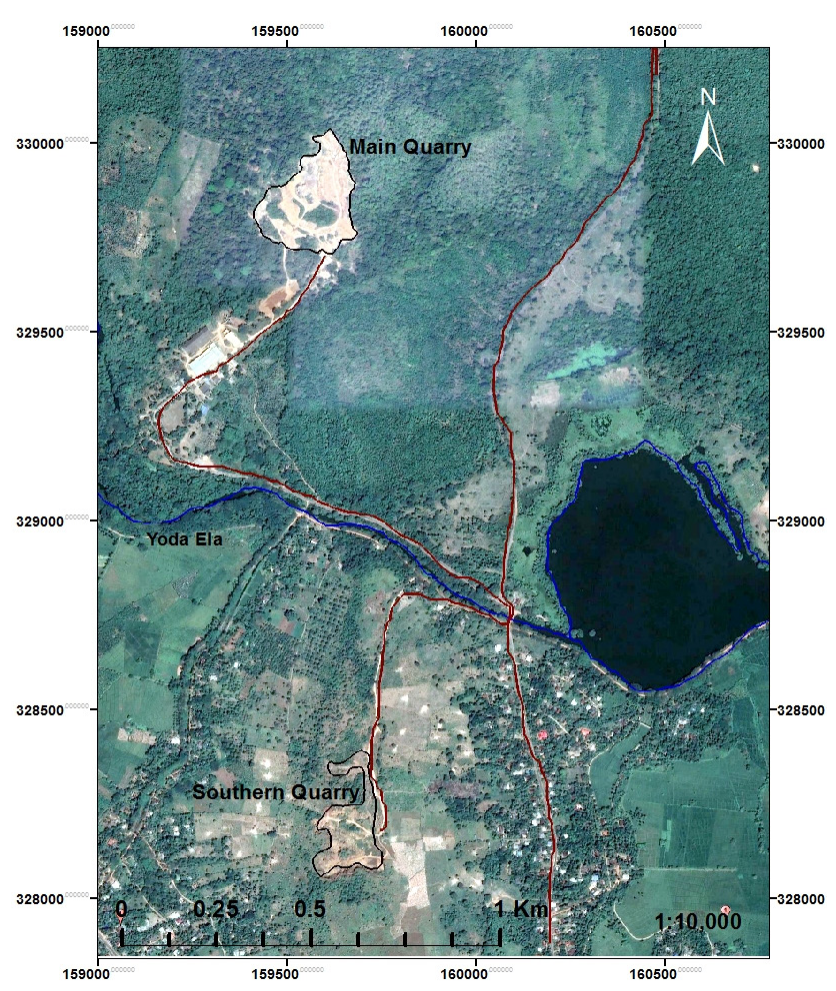

Figure 2: The map showing the aerial view of the study site.

\section{MATERIAL AND METHODS}

\section{Sample collection and preparation}

Representative weathered carbonatite samples were collected from the sequence of the weathering horizons distinguishable at various depth levels [Figure 3(a)] of the cut slope exposed during the strip mining of the phosphate quarry, as shown in Figure 3(b). The weathering zones of the profiles have been demarcated based on textural characteristics, mineralogical composition and nature of the matrix, as well as physical properties, such as colour, porosity and nature of compaction. Samples were stored in airtight polyethylene bags and the preparation steps before the analyses were done at the Department of Geology, University of Peradeniya. The samples were absent of any anthropogenic material.

\section{Specific characteristics of selected samples}

ES-P1S1: The sample was collected at $5.6 \mathrm{~m}$ depth from the surface level. The matrix of the sample is yellowish brown and less consolidated [appeared as consolidated in Figure $3(\mathrm{~b})$ ]. The porosity of the matrix was high due to the presence of pores and cavities formed by dissolution of weather prone minerals. Primary apatite crystals were 
slightly brecciated. Apatite crystals were larger in size (the majority is in the decimeter range) and modal percentage of apatite was high. As per the field observations, the sample belongs to the alloteritic-saprollite zone of the weathering profile.

ES-P1S2, ES-P1S3 and ES-P1S4: Three representative samples were collected from the intensively weathered leached zone of the profile at $3.8 \mathrm{~m}, 2.0 \mathrm{~m}$ and $1.0 \mathrm{~m}$ depth levels, respectively, from the surface. The matrix was dark brownish and highly consolidated. The porosity of the sample was very low due to the high compaction of the matrix. Primary apatite crystals were highly brecciated while their modal percentage was high. Mineralization of secondary products with light and dark thin laminations characterized the zone.

ES-P1S5: The representative sample was collected from the surface of the deposit and it belonged to the extremely weathered lateritic soil layer of the profile. The soil layer was dark brownish to black and abundant with loosely bound, angular to sub-angular grains of apatite and secondary phosphate material. The apatite content was very low and the clay content was high.

The separation of primary apatite crystals embedded in the matrix was done by handpicking. Each matrix fraction was dried in a laboratory oven at $110^{\circ} \mathrm{C}$ for $24 \mathrm{~h}$ to remove moisture. A representative aliquot of each matrix sample was pulverized using an agate mortar and pestle until the particle size became finer than $75 \mu \mathrm{m}$.

\section{Mineralogical analysis}

Powder X-ray diffraction (PXRD) analysis was carried out on D8 ADVANCE powder X-ray Diffractometer (Bruker, Germany) at the Postgraduate Institute of Science,
University of Peradeniya. Powder diffraction patterns were collected using $\mathrm{Cu}-\mathrm{K} \alpha$ radiation, with 0.02 theta step size, between $10^{\circ}$ to $90^{\circ}$ two theta range.

\section{Chemical analyses}

Representative portions of each powdered sample were subjected to geochemical analysis at Intertek Genalysis Laboratory, Western Australia. Sample digestion was conducted by the borax bead method, where each sample was mixed with lithium tetraborate in a platinum crucible and fused at $1000{ }^{\circ} \mathrm{C}$ in an automated furnace to obtain a molten bead. In the next step, the molten beads were dissolved in nitric acid and the resulting nitrate solutions comprising major, trace and rare earth elements were analyzed using Inductively Coupled Plasma-Optical Emission Spectrometer (ICP-OES) (Agilent Technologies, USA) and Inductively Coupled Plasma-Mass Spectrometer (ICP-MS) (Agilent Technologies, USA). Loss on ignition (LOI) was determined by calcination of each sample in a muffle furnace at $1000^{\circ} \mathrm{C}$.

\section{RESULTS AND DISCUSSION}

\section{Weathering profile of ES quarry site}

Zonations of the weathering profile

The weathering process of carbonatite is deemed to be much complicated which creates complex weathering profiles. Some profiles which have not been subjected to karstic weathering show developed zonations as patches or lenses due to weathering processes. These zoned areas are distinguished by textural and structural features, as well as presence of supergene minerals and matrices developed at different stages. (a)

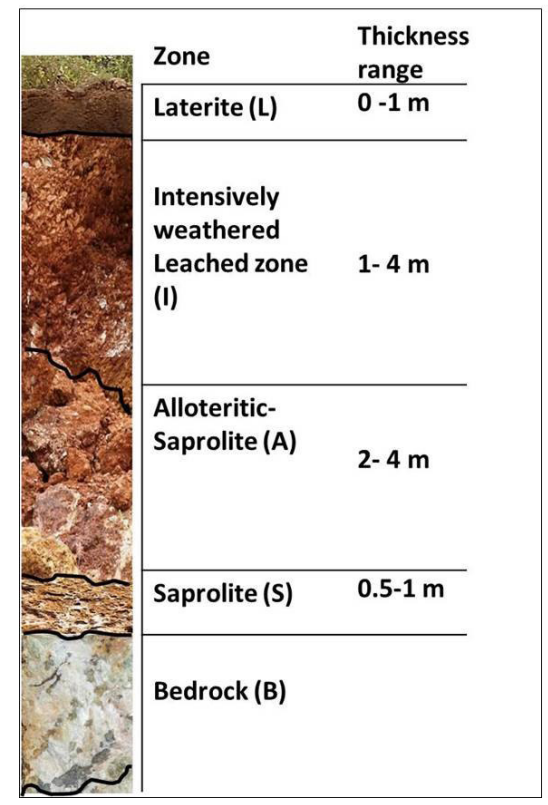

(b)

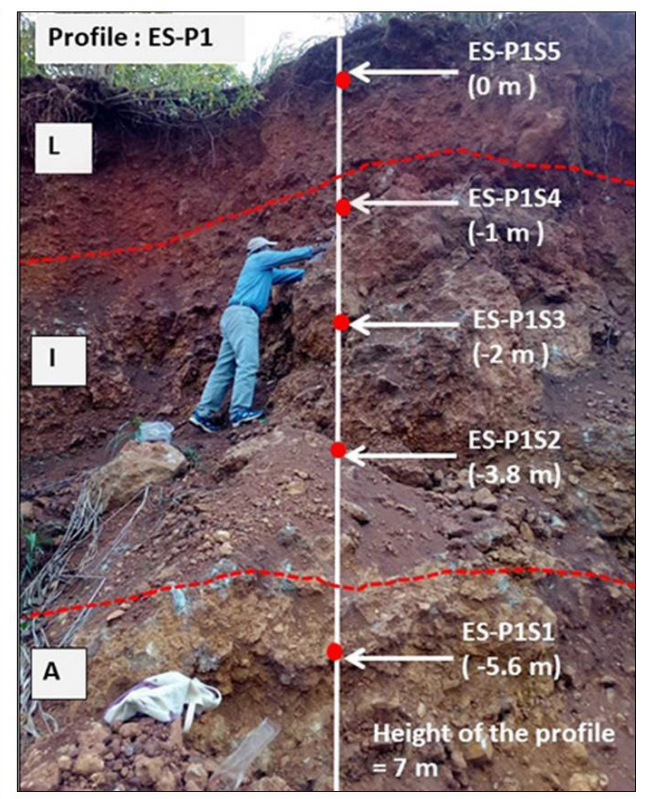

Figure 3: (a) Schematic diagram showing the zonations of the profile of ES with layer thickness ranges, L - lateritic zone; I - intensively weathered leached zone; A - alloteritc-saprolite zone, S -Saprolite, B - Bed rock (b) Photograph of selected weathered profile showing sampling points of the different zones (L, I, and A are labeled as shown above). 
The weathered profiles of the study site are more equivalent in structure and mineralogy than the weathering products formed at the major quarry site in the northern region. Further, the saprolitic zone occurs in only a few locations and has not been commonly found in the study area. The weathering profiles exhibit four main horizons, namely (i) fresh to partially weathered carbonatite zone, (ii) alloteritic- saprolite zone, (iii) intensively leached zone and (iv) lateritic zone [Figure 3(a)].

The alloteritic-saprolite zone is characterized by the primary minerals which are less brecciated in the intensely weathered parent rock which consists of high intensity of cavities and pores. The yellowish brown ground mass is reckoned to be less consolidated than the upper layers of the profile and the maximum thickness of the layer is approximately $4 \mathrm{~m}$. Dark brown colored loose materials with weathering resistant primary minerals are widespread in the zone just above the parent rock.

In the intensively leached zone, weather-resistant primary minerals are embedded in the hard and consolidated brownish ground mass rich in iron oxides and secondary phosphate materials. The apatite concentration was mostly high and the crystal sizes were ranging from few millimeters to several centimeters. The primary minerals remaining in the matrix are highly brecciated. The average thickness of the layer is $4 \mathrm{~m}$.

The uppermost layer of the profile appeared as lateritic soil, with a thickness varying from a few centimeters to approximately $1 \mathrm{~m}$. In most areas of the

(a)
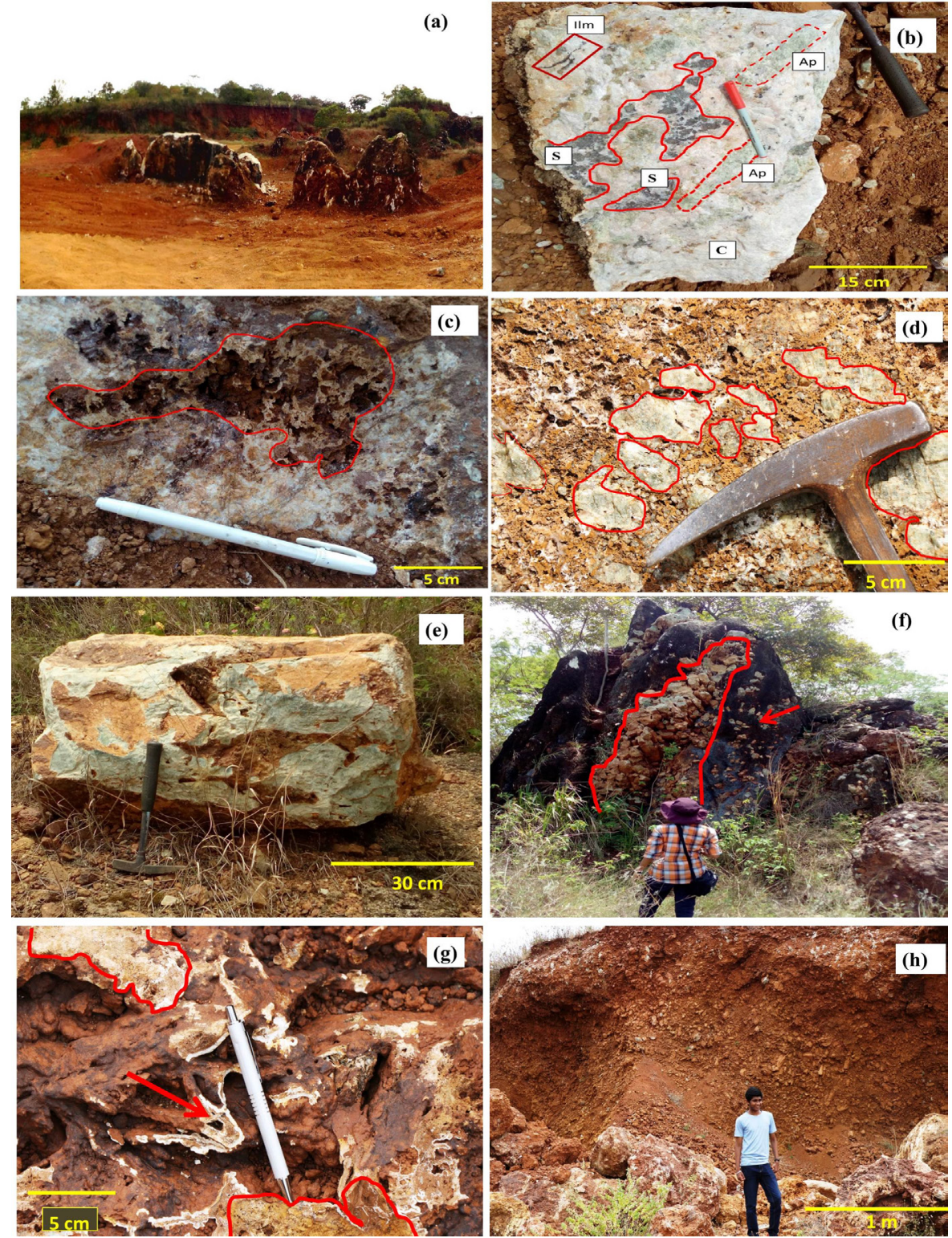

Figure 4: Field photographs showing (a) Elongated carbonatite exposures near the vicinity of the weathered profile showing intense karstic weathering (b) Fresh carbonatite with the un-weathered primary minerals (Ap - apatite, Ilm - ilmenite, S - segregated silicate minerals arranged in one direction within the $\mathrm{C}$ - carbonate matrix) (c) and (d) Formation of variable ranges of cavities due to partial dissolution of carbonate minerals (e) Part of a massive apatite crystal indicating the variation in size of crystals in the parent rock (f) Clusters of large primary apatite crystals collapsed in to a developed larger cavity, the red arrow indicates the mode of occurrences of apatite crystals in the carbonatite (g) Lamination formed by the re-precipitation of dissolved phosphates (h) The upper zones of the weathered profile with unconsolidated material and hard and compacted boulders collected from the lower layers. 
quarry, the upper layer has been removed owing to mining activities or is covered by heavy vegetation. The soil layer is rich with loose granular particles which are almost angular to sub-angular in shape. They are usually primary apatite and secondary phosphate fragments that have been coasted by recent secondary materials.

\section{Successive formation stages of the phosphate ores}

Fresh carbonatite exposures [Figure 4(a)] are composed of mainly carbonates (calcite and dolomite) with minor large euhedral primary apatite grains, segregated aggregates of silicate minerals and iron oxide minerals (Madugalla et al., 2017; Manthilake et al., 2008; Pitawala and Lottermoser, 2012) as shown in Figure 4(b). Several physicochemical processes occurred in the parent rocks during the early stages of weathering, which can be explained as follows.

The development of small scale cavities ranging in size from a few millimeters to a few centimeters occurs from the partial or complete dissolution of carbonate minerals with the preservation of weathering resistant apatite, silicates and other minerals [Figure 4(c) and 4(d)]. During the initial stages of the carbonatite weathering, the dissolution of $\mathrm{CO}_{2}$ in water reduces the $\mathrm{pH}$ conditions (Black et al., 2015; Luquot and Gouze, 2009). Carbonates are the most weather-prone minerals which tend to initialize the dissolution reactions first while other primary minerals such as silicates and apatite are secured (Vieillard et al., 1979; Broom-Fendley et al., 2020). Carbonate dissolution of rocks occurs under three steps where (i) acidic solutions are transported by diffusion and advection to the solid particle surfaces of the porous rock (ii) several chemical dissolution reactions occur at the solid particle surfaces of the porous rock and (iii) the products of the chemical dissolution reaction are transported away from the solid particle surfaces of the porous rock (Zhao et al., 2013). The resulting porous nature accelerates the weathering rate by increasing permeability, providing more surface area for the dissolution reactions (Gu et al., 2020; Luquot and Gouze, 2009).

Dissolution reactions of carbonate minerals [reactions (1) and (2) for dissolutions of calcite and dolomite, respectively] release $\mathrm{CO}_{2}(\mathrm{~g})$ which hydrolyses to form carbonic acid (Lerman and Mackenzie, 2018; Martin, 2017). Similarly, the dissolution of $\mathrm{CO}_{2}$ in meteoric water and $\mathrm{CO}_{2}$ available in the soil yields the same acidic product.

$$
\begin{gathered}
\mathrm{CaCO}_{3}+2 \mathrm{H}^{+} \rightarrow \mathrm{Ca}^{2+}+\mathrm{H}_{2} \mathrm{O}+\mathrm{CO}_{2} \\
\text { Ca.Mg }\left(\mathrm{CO}_{3}\right)_{2}+4 \mathrm{H}^{+} \rightarrow \mathrm{Ca}^{2+}+\mathrm{Mg}^{2+}+2 \mathrm{H}_{2} \mathrm{O}+2 \mathrm{CO}_{2}
\end{gathered}
$$

All these processes increase the acidity of the weathering environment, providing $\mathrm{pH}$ conditions adequate for the dissolution of clastic apatite crystals. Upon further dissolution of carbonate minerals for prolonged time, even larger cavities and fissures can be developed along the weaker zones of rocks (Abd El Aal, 2017; Erdosh, 1979). Many of the large apatite crystals in the deposits have not been subjected to acidic conditions during weathering
[Figure 4(e)]. It may be because of the smooth crystal surface of them, which is incapable of interacting with percolating water or falling into highly porous cavities where the solutions cannot stagnate.

As a result of gravity forces, apatite and other primary minerals together with the weathered carbonate matrix lying above the cavities tend to collapse down to the large cavities, creating depressions (Erdosh, 1979; Broom-Fendley et al., 2020). As a result, there is a strong propensity to mix up the older and younger weathered material together during the weathering process. Such karstic environmental features are present in the parent rock in the study site as shown in Figure 4(f). Therefore, the development of phosphate ores in the area has been influenced by complex weathering processes along with pedological and mineralogical variations.

Silicate minerals present in the parent rock, such as forsterite and enstatite, are less resistant to weathering and have been altered to form both iron oxides and clay minerals in the presence of water at (Churchman et al., 2012). High weather-resistant iron oxides, such as ilmenite, rutile and magnetite, are leftover in the lower layers of the weathering profile. However, these residual iron oxides tend to oxidize upon intense weathering conditions.

When weathering continues, the material accumulated in the cavities and fissures starts the dissolution processes. As a result of fluctuations of the weathering conditions prevailing in the environment, various minerals tend to re-precipitate from the solutions [Figure 4(g)]. Due to overlying weight, the resulting material is squeezed, compacted and later on, cemented by forming hard materials. This hard and compacted material has undergone the mixing process several times by collapsing, followed by accumulating in cavities (Figure 5).

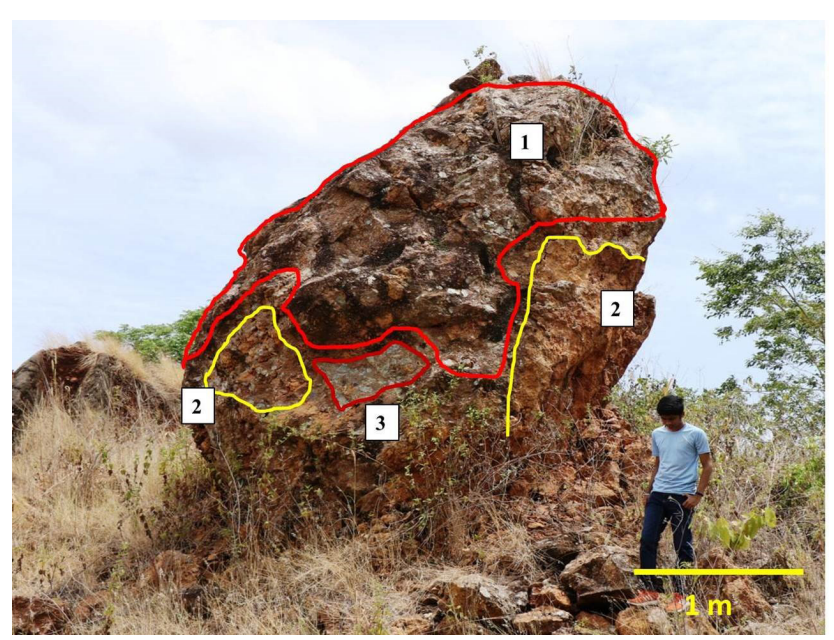

Figure 5: Different zones showing the mixing of weathered products under karst conditions; zones numbered 1 and 3 indicate weathered products with highly compacted bodies with a strongly cemented matrix signifying the older generations; zones numbered 2 are made up of unconsolidated yellowish materials with primary apatite implying younger weathered products. 


\section{Supergene minerals and their paragenesis}

The weathered ore is made up of weather-resistant primary minerals as well as least-altered and large number of supergene minerals (Figure 6). The presence of several generations of secondary phosphate, oxide, carbonate and silicate minerals has been identified from the current study, in addition to the secondary minerals found in the literature. It is possible that the selected profile represents several weathering zones that are not present in the main quarry.

The areas corresponding to the alloteritic-saprolite zone [Figure 6(a)] is mainly made of primary apatite, secondary phosphates and iron oxide minerals in the yellowish-brown groundmass. Fluorapatite (FA) with the composition of $\left[\mathrm{Ca}_{5}\left(\mathrm{PO}_{4}\right) \cdot \mathrm{F}\right]$ is the dominant apatite type present in the zone while several secondary phosphate phases, such as carbonated-fluorapatite (C-FA) with the formula of $\left[\mathrm{Ca}_{5}\left(\mathrm{PO}_{4}, \mathrm{CO}_{3}\right)\right.$.F $]$ and minor amount of gorceixite $\left[\mathrm{BaAl}_{3}\left(\mathrm{PO}_{4}\right)\left(\mathrm{PO}_{3} \mathrm{OH}\right)(\mathrm{OH})_{6}\right]$, florencite $\left[\mathrm{CeAl}_{3}\left(\mathrm{PO}_{4}\right)_{2}(\mathrm{OH})_{6}\right]$ and goyazite $\left[\mathrm{SrAl}_{3}\left(\mathrm{PO}_{4}\right)\left(\mathrm{PO}_{3} \mathrm{OH}\right)(\mathrm{OH})_{6}\right]$ are present in the matrix. Goethite $[\alpha-\mathrm{FeO}(\mathrm{OH})]$ is the major iron oxide constituent in the secondary matrix. Quartz
$\left(\mathrm{SiO}_{2}\right)$, gobbinsite $\left[\mathrm{Na}_{5}\left(\mathrm{Si}_{11} \mathrm{Al}_{5}\right) \mathrm{O}_{32} \cdot 11 \mathrm{H}_{2} \mathrm{O}\right]$ and bikitaite $\left[\mathrm{Li}_{2} \mathrm{Al}_{2}\left(\mathrm{Si}_{2} \mathrm{O}_{6}\right)_{2} \cdot 2\left(\mathrm{H}_{2} \mathrm{O}\right)\right]$ are the silicate minerals.

The leached zone [Figure 6(b, c and d)] is composed of weather-resistant primary FA and iron oxide minerals, such as ilmenite $\left(\mathrm{FeTiO}_{3}\right)$, embedded in the secondary formed hard and consolidated dark brown matrix. The matrix consists of various types of secondary phosphates, oxides and silicates. Fresh or slightly altered primary apatites in the leached zone are mainly FA, together with minor amount of C-FA and carbonated-hydroxylapatite (C-HA) with the formula of $\left[\mathrm{Ca}_{5}\left(\mathrm{PO}_{4}, \mathrm{CO}_{3}\right) . \mathrm{OH}\right]$. The secondary phosphate varieties in the zone are mainly crandallite $\left[\mathrm{CaAl}_{3}\left(\mathrm{PO}_{4}\right)\right.$ $\left.\left(\mathrm{PO}_{3} \mathrm{OH}\right)(\mathrm{OH})_{6}\right]$ and florencite $\left[\mathrm{CeAl}_{3}\left(\mathrm{PO}_{4}\right)_{2}(\mathrm{OH})_{6}\right]$ with minor occurrences of goyazite $\left[\mathrm{SrAl}_{3}\left(\mathrm{PO}_{4}\right)\left(\mathrm{PO}_{3} \mathrm{OH}\right)(\mathrm{OH})_{6}\right]$ and gorceixite $\left[\mathrm{BaAl}_{3}\left(\mathrm{PO}_{4}\right)\left(\mathrm{PO}_{3} \mathrm{OH}\right)(\mathrm{OH})_{6}\right]$. Goethite is present as the oxidized product of primary iron oxide minerals. Moreover, various silicate minerals, such as quartz, zeolite group minerals [gobbinsite $\left[\mathrm{Na}_{5}\left(\mathrm{Si}_{11} \mathrm{Al}_{5}\right)\right.$ $\left.\mathrm{O}_{32} \cdot 11 \mathrm{H}_{2} \mathrm{O}\right]$ and heulandite $\left.\left[(\mathrm{Ca}, \mathrm{Na})_{5}\left(\mathrm{Si}_{27} \mathrm{Al}_{9}\right) \mathrm{O}_{72} \cdot 26 \mathrm{H}_{2} \mathrm{O}\right)\right]$ which have not been reported in literature are present in the matrix. Magnesite $\left(\mathrm{MgCO}_{3}\right)$ and rhodochrosite $\left(\mathrm{MnCO}_{3}\right)$ may either be primary or secondary carbonate formations. The laminations with variable thicknesses and colors

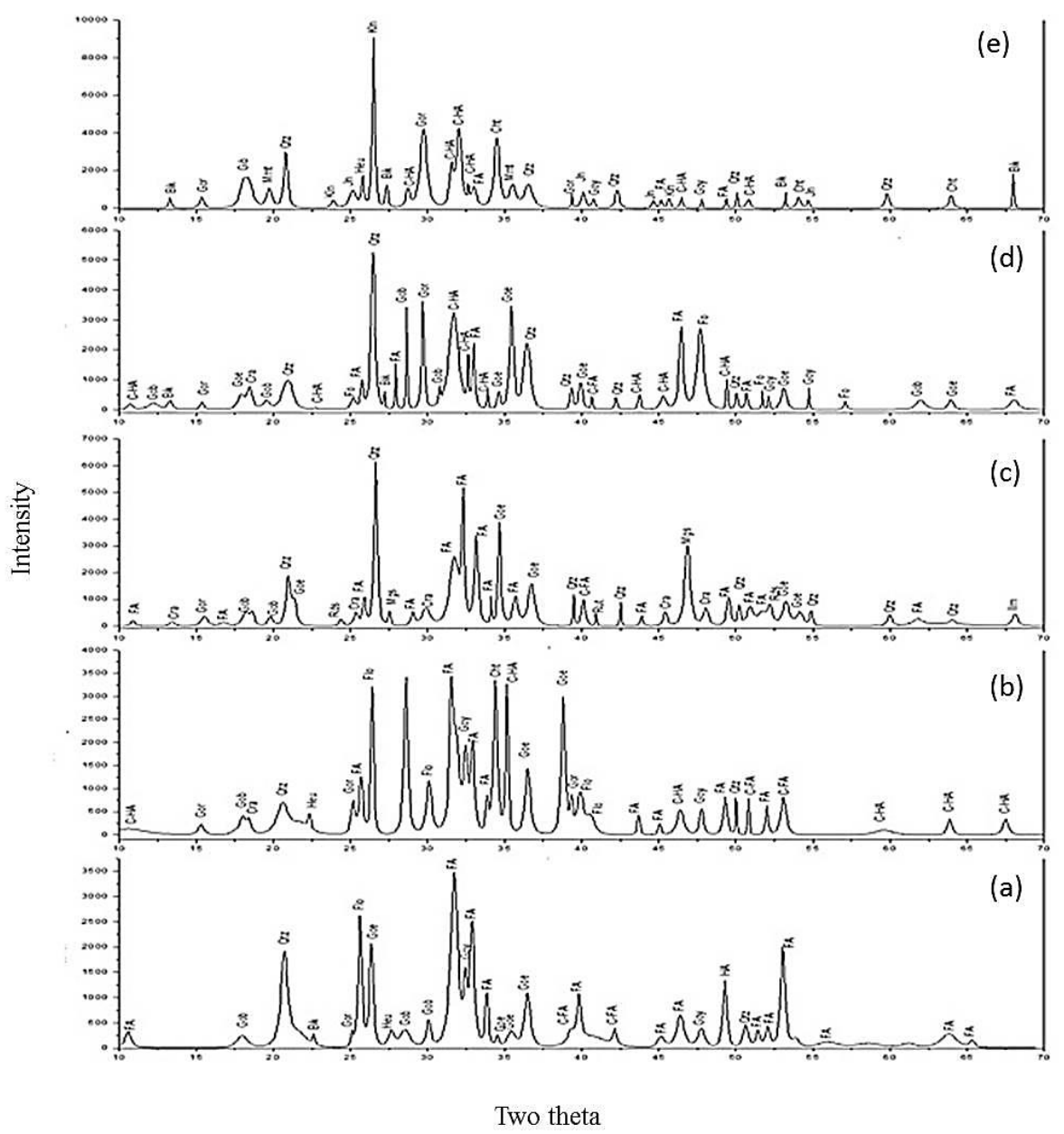

Figure 6: (a) to (e) Powder X-Ray diffractograms showing the mineralogy of the weathered samples from bottom (ES-P1S1) to the top (ES-P1S5) of the profile; FA: fluorapatite, C-FA: carbonate fluorapatite, C-HA: carbonate-hydroxylapatite, Goe: goethite, Gor: gorceixite, Cra: crandallite, Flo: florencite, Gob: gobbinsite, Goy: goyazite, Qtz: quartz, Bik: bikitaite, Heu: heulandite, Cht: chantalite, Kln: kaolinite, Mmt: montlorillonite, Fo: forsterite, Jn: Junitoite, Gib: gibbsite, Rut: rutile, Ilm: ilmenite, Rds: Rhodochrosite, Mgs: Magnesite. 
indicate the formation of different generations of secondary products during various stages of weathering.

The PXRD pattern of the sample corresponding to lateritic soil [Figure 6(e)] exhibits the presence of elevated levels of silicate minerals, especially clay minerals; mainly montmorillonite $\quad\left[(\mathrm{Na}, \mathrm{Ca})(\mathrm{Al}, \mathrm{Mg})_{2}\left(\mathrm{Si}_{4} \mathrm{O}_{10}\right)(\mathrm{OH})_{2} \cdot \mathrm{H}_{2} \mathrm{O}\right]$ with minor kaolinite $\left[\mathrm{Al}_{2}\left(\mathrm{Si}_{2} \mathrm{O}_{5}\right)(\mathrm{OH})_{4}\right]$. Other silicate phases present in the zone are bikitaite, junitoite, chantalite $\left[\mathrm{CaAl}_{2}\left(\mathrm{SiO}_{4}\right)(\mathrm{OH})_{4}\right]$ and heulandite. Apatite minerals content is deemed low due to intense weathering conditions. FA and various secondary phosphate phases, such as C-HA, gorceixite, crandallite and goyazite, are noticed. Further, mineralization of goethite and gibbsite as a result of the lateratization process was observed.

The paragenesis of the above supergene minerals can be described with the aid of mineralogical composition of parent carbonatite and the possible substitution reactions which can be taken place based on the ion availability. The apatite phase present in the parent carbonatite is chlorofluoro-hydroxyl apatite (CFHA). FA is the first product formed by the substitution reactions of CFHA during the early stages of weathering. The genesis of FA can be related to leaching of $\mathrm{Cl}^{-}$and $\mathrm{OH}^{-}$from the apatite structure (Hewawasam, 2013). The lower and intermediate zones of the weathered ores are rich in FA. The direct crystallization of FA is only possible from the solution rich with $\mathrm{F}^{-}$ions. In the next stages, carbonate ions evolved by dissolution of primary carbonate minerals can substitute the phosphate ions into the structure of the FA and form C-FA (Leroy et al., 2001; Tacker, 2008). Upon adequate physicochemical conditions, apatite structure tends to dissolve and leach out $\mathrm{Ca}^{2+}, \mathrm{PO}_{4}^{3-}$ and other cations such as REEs to the solution. Based on the cation availability of the weathering solution, numerous secondary phosphates tend to precipitate from the solution and recrystallize within the weak zones in the karst environment. As a result with the considerable amounts of $\mathrm{Al}^{3+}$ (derived from weathering products of silicate rocks) and $\mathrm{Ca}^{2+}$ in the solution alumino-phosphate and crandallite can be precipitated (Hewawasam, 2013). Further, based on the available cations, such as REEs, $\mathrm{Ba}$ and $\mathrm{Sr}$, the mineralization of other plumbogummite group members, namely, florencite (REEs rich), goyazite (Ba rich) and gorceixite (Sr rich), respectively, have taken place (Flicoteaux and Lucas, 1984). Mineralization of such alumino-phosphates in the near surface layers of the phosphate regolith overlying carbonatites in the world was reported by several researchers (Decree et al., 2016; Van Gosen et al., 2017). According to the literature, occurrences of the above mentioned latter two plumbogummite minerals have not been reported in previous studies on Eppawala phosphate ores.

Goethite is an oxidation product of iron oxide minerals such as magnetite favored by $\mathrm{pH}$ and temperature (He and Traina, 2007). Smectile group clay formation are inherited from the breakdown of primary silicates, such as olivine and pyroxene of the parent carbonates or from weathering of host granitic gneiss (Churchman et al., 2012).

The genesis of gibbsite in a tropical environment can be explained using two different scenarios where the formation of gibbsite by direct weathering of primary alumino-silicates or transformation through clay mineral intermediates (Bhattacharyya et al., 2000). The presence of high amounts of silicate minerals in the weathered profile provides the hues of mixed up carbonatite and country-rock during the weathering process.

\section{Concentration (Wt \%)}

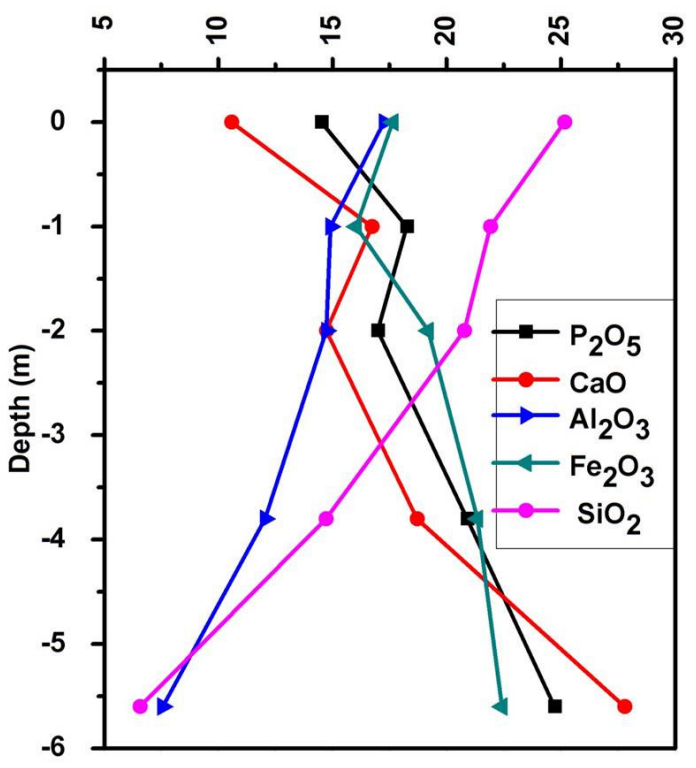

(a)

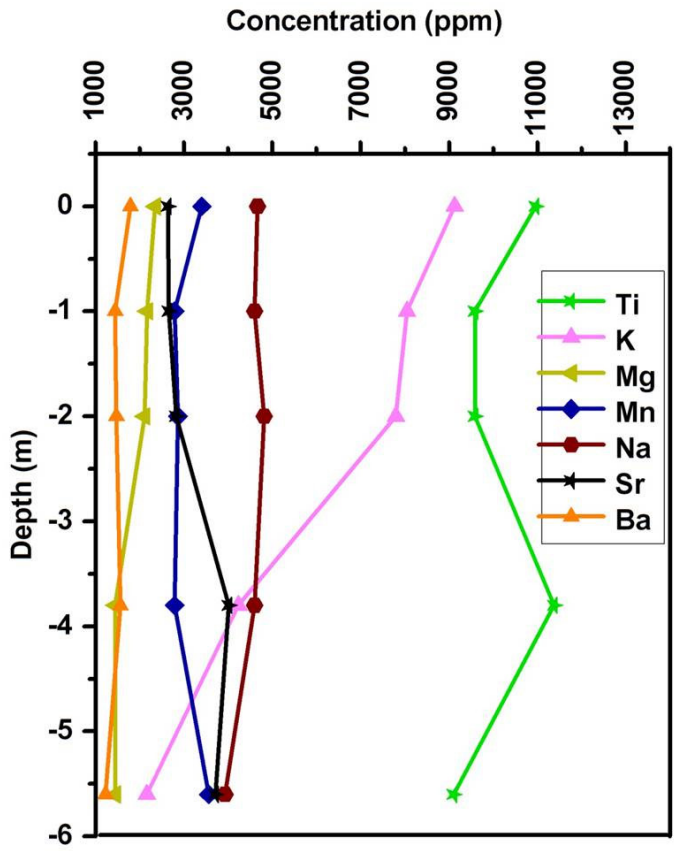

(b)

Figure 7: Anomaly of (a) major oxides concentrations (wt\%) (b) minor element concentrations (ppm) with the depth. 


\section{Geochemistry of the weathered profile}

Behavior of major oxides and minor elements within the profile

The dominant components in the weathered profile are $\mathrm{P}_{2} \mathrm{O}_{5}, \mathrm{CaO}$ and $\mathrm{Fe}_{2} \mathrm{O}_{3}$ together with notable amounts of $\mathrm{Al}_{2} \mathrm{O}_{3}$ and $\mathrm{SiO}_{2}$ (Table 1). The $\mathrm{CaO}$ component present in the parent rock has been lost by approximately $30 \mathrm{wt} \%$, whereas the $\mathrm{CaO}$ content measured in the parent carbonatite is $46-53 \mathrm{wt} \%$. This has been attributed by the dissolution and removal of carbonaceous forms (mainly calcite and dolomite) in the bed rock while the remaining amount $(10-27 \mathrm{wt} \%)$ in the profile is related to the primary apatites and secondary products, such as secondary phosphates and clay minerals.

$\mathrm{P}_{2} \mathrm{O}_{5}$ content in weathered profile varies from $25 \mathrm{wt} \%$ at the bottom to $15 \mathrm{wt} \%$ at the upper lateritic level of the profile which is several times higher than the amount of parent rock. $\mathrm{P}_{2} \mathrm{O}_{5}$ concentration tends to decrease towards the upper layer of the deposit. The corresponding pattern is related to the accumulation of residual apatite and secondary phosphate products in the upper alloteriticsaprolite zone and lower levels of the leached zone followed by successive weathering at the higher levels of the profiles. Strong correlation of $\mathrm{P}_{2} \mathrm{O}_{5}$ and $\mathrm{CaO}$ content patterns in the profile can be confirmed by the data obtained from the field investigations and mineralogical analysis.

The presence of alumina and silica at higher levels than normal weathered profiles generated from carbonatite bed rock is the most significant finding of the current study. Both oxides show a distinct increasing trend towards the surface and similar fluctuations in concentrations within the profile. The silicate and alumina content in the parent carbonatite whole rock data is very low (Table 1). As a result, such an increase cannot be attributed to secondary mineralization from primary silicate minerals such as olivine and pyroxene in carbonatites. Low silicate content in the source rock and higher $\mathrm{SiO}_{2}$ and $\mathrm{Al}_{2} \mathrm{O}_{3}$ values in the weathered profile show that weathering products from both country rock and carbonatites were mixed. The fluctuations in $\mathrm{Fe}_{2} \mathrm{O}_{3}$ within the weathered zone are much less than other major oxides [Figure 7(a)].

Despite the fact that $\mathrm{K}_{2} \mathrm{O}$ and $\mathrm{TiO}_{2}$ concentrations of the parent rock are low (Table 1), the samples studied are characterized by higher levels. $\mathrm{K}_{2} \mathrm{O}$ contents increase towards to the surface. The similar variations of $\mathrm{K}_{2} \mathrm{O}$ and $\mathrm{SiO}_{2}$ imply the input of external sources of these elements. Concentration pattern of $\mathrm{Mg}, \mathrm{Mn}, \mathrm{Na}, \mathrm{Sr}$ and $\mathrm{Ba}$ deemed to be absent with significant variations.

Concentration variations of major oxides and minor elements with the depth of the profile are depicted in separated plots [Figure 7(a) and (b) respectively].

\section{REEs anomalies in the profile}

The total REE( $\Sigma$ REEs) concentrations of weathered samples vary between 3072 and 5222 ppm (Table 1). These values are much greater than those found in parent carbonatites, which range from 347 to 885 ppm (Pitawala et al., 2003).
The samples are enriched with light rare earth elements (LREEs) where the $(\mathrm{La} / \mathrm{Lu}) \mathrm{CN}$ ratios range from 34.60 to 44.45 , indicating that $\mathrm{La}$ and $\mathrm{Lu}$ experienced systematical fractionation upon the weathering of carbonatite. The depth profile shown in Figure 8 exhibits that the intensity of the $(\mathrm{La} / \mathrm{Lu}) \mathrm{CN}$ values gradually increases, when moving toward the deeper layers of the profile. The heavy rare earth elements (HREEs) are more mobile than their lighter counterparts, LREEs (Ling et al., 2015). During the weathering of REEs bearing primary minerals, HREEs tend to create stronger complexes with carbonate ligands which have higher migration ability and escape away. The low solubility of these HREEs complexes hinders the ability to sorb them into REEs scavenging particles (Maria et al., 1998; Tang and Johannesson, 2003). The vertical distribution pattern of $\Sigma$ REEs depicts a downward movement of the elements and there is no significant upward migration of REEs. This can be attributed to the leaching of REEs from upper layers, movement through migration paths and accumulation in lower layers of the profile (Janots et al., 2015). There is no discernible upward movement enrichment of REEs, which is expected during late diagenetic recrystallization and adsorption by crystal surfaces (Reynard, Lécuyer and Grandjean, 1999) as has been documented in various carbonatites across the world (Lottermoser, 1990; Joosu et al., 2015; Anenburg et al., 2018).

The higher REEs anomalies in the upper alloteriticsaprolite and lower leached zone of the profile have been inherited from the REEs held by various scavenging substances, such as secondary alumino-phosphates and iron oxide minerals. In the uppermost lateritic layers, montmorillonite acts as REEs traps.

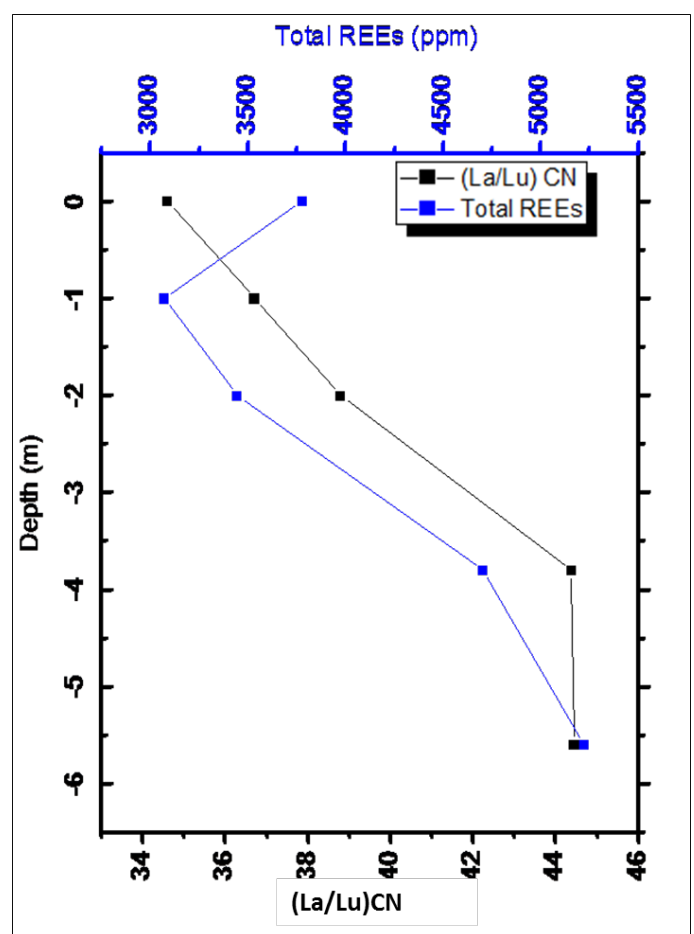

Figure 8: Variation of total REEs and $(\mathrm{La} / \mathrm{Lu}) \mathrm{CN}$ with depth of the profile. 
Table 1: Major oxides, trace and REEs concentrations of the ES-P1 weathered profile (present study) and carbonatite (Pitawala et al., 2003). Sample depth was measured from the surface level of the current mining site. (LoD - concentration less than the limit of detection; LOI: Loss on ignition; N.M: Not measured).

\begin{tabular}{|c|c|c|c|c|c|c|}
\hline & \multirow{2}{*}{ Carbonatite } & \multicolumn{5}{|c|}{ ES-P1 Weathering profile } \\
\hline & & ES-P $\mathbf{P}_{1} \mathbf{S}_{1}$ & ES-P $\mathbf{P}_{1} \mathrm{~S}_{2}$ & ES-P $\mathbf{P}_{1}$ & ES-P $\mathbf{P}_{1} \mathbf{S}_{4}$ & ES-P $\mathbf{P}_{1} \mathbf{S}_{5}$ \\
\hline Depth (m) & N.M & -5.6 & -3.8 & -2.0 & -1.0 & 0 \\
\hline \multicolumn{7}{|c|}{ Major Oxides (wt\%) } \\
\hline $\mathbf{P}_{2} \mathbf{O}_{5}$ & $0.01-10.58$ & 24.73 & 20.89 & 16.98 & 18.25 & 14.51 \\
\hline $\mathrm{CaO}$ & $46.31-52.81$ & 27.79 & 18.7 & 14.74 & 16.72 & 10.57 \\
\hline $\mathrm{Al}_{2} \mathrm{O}_{3}$ & $0.01-0.09$ & 7.56 & 12.05 & 14.74 & 14.91 & 17.26 \\
\hline $\mathrm{Fe}_{2} \mathrm{O}_{3}$ & $0.31-1.22$ & 22.42 & 21.35 & 19.19 & 16.03 & 17.64 \\
\hline $\mathrm{K}_{2} \mathrm{O}$ & LoD & 0.26 & 0.51 & 0.94 & 0.97 & 1.1 \\
\hline MgO & $2.16-9.24$ & 0.24 & 0.24 & 0.35 & 0.36 & 0.39 \\
\hline MnO & $0.05-0.09$ & 0.46 & 0.36 & 0.37 & 0.36 & 0.44 \\
\hline $\mathrm{Na}_{2} \mathrm{O}$ & $0.02-0.05$ & 0.53 & 0.62 & 0.65 & 0.62 & 0.63 \\
\hline $\mathrm{SiO}_{2}$ & $0.04-0.41$ & 6.56 & 14.72 & 20.77 & 21.91 & 25.16 \\
\hline $\mathrm{TiO}_{2}$ & LoD & 1.52 & 1.9 & 1.6 & 1.6 & 1.83 \\
\hline LOI-1000 & $32.24-44.94$ & 8.23 & 9.03 & 10.35 & 8.71 & 11.18 \\
\hline Total & $94.82-101.71$ & 100.3 & 100.37 & 100.68 & 100.44 & 100.71 \\
\hline Sr (ppm) & $2960-6819$ & 3717.1 & 4014.5 & 2825.9 & 2656.2 & 2636.8 \\
\hline Ba (ppm) & $66.6-685.0$ & 1225.1 & 1563.8 & 1472.1 & 1442.5 & 1790.0 \\
\hline \multicolumn{7}{|l|}{ REEs (ppm) } \\
\hline Sc & N.M & 18.0 & 18.0 & 18.0 & 15.0 & 19.0 \\
\hline $\mathbf{Y}$ & $38.5-68.9$ & 205.8 & 176.8 & 144.5 & 131.3 & 170.8 \\
\hline La & $53.8-153.0$ & 987.4 & 900.0 & 674.4 & 602.6 & 735.2 \\
\hline $\mathrm{Ce}$ & $112.0-354.0$ & 2189.2 & 1968.6 & 1435.6 & 1273.5 & 1561.7 \\
\hline $\operatorname{Pr}$ & $15.2-48.9$ & 275.6 & 252.2 & 180.5 & 160.7 & 196.6 \\
\hline Nd & $65.0-192.0$ & 1128.0 & 1022.7 & 724.3 & 646.8 & 786.9 \\
\hline $\mathrm{Sm}$ & $13.8-31.5$ & 178.4 & 155.0 & 109.7 & 99.4 & 122.9 \\
\hline $\mathbf{E u}$ & $2.5-7.0$ & 35.4 & 31.0 & 22.7 & 19.8 & 24.7 \\
\hline Gd & $12.2-20.1$ & 102.0 & 88.36 & 63.89 & 57.37 & 74.47 \\
\hline $\mathbf{T b}$ & $1.4-2.1$ & 10.1 & 9.1 & 7.0 & 6.1 & 7.7 \\
\hline Dy & $6.9-10.2$ & 45.3 & 40.9 & 31.1 & 28.9 & 36.8 \\
\hline Ho & $1.2-1.8$ & 7.5 & 6.6 & 5.3 & 4.9 & 6.2 \\
\hline $\mathbf{E r}$ & $3.0-6.4$ & 19.1 & 16.5 & 13.6 & 12.5 & 16.5 \\
\hline Tm & $0.4-0.7$ & 2.6 & 2.2 & 1.8 & 1.6 & 2.3 \\
\hline $\mathbf{Y b}$ & $2.3-3.9$ & 14.9 & 13.6 & 11.3 & 9.9 & 14.6 \\
\hline $\mathbf{L u}$ & $0.4-0.6$ & 2.3 & 2.1 & 1.8 & 1.7 & 2.2 \\
\hline ¿REEs & $347.3-885.0$ & 5221.7 & 4703.7 & 3445.5 & 3072.1 & 3778.6 \\
\hline ¿LREES & $262.3-784.4$ & 4896.1 & 4417.9 & 3211.1 & 2860.2 & 3502.5 \\
\hline ¿HREEs & $67.3-107.6$ & 307.6 & 267.8 & 216.4 & 196.9 & 257.1 \\
\hline 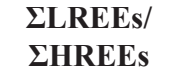 & $3.1-7.8$ & 15.9 & 16.5 & 14.8 & 14.5 & 13.6 \\
\hline (La/Lu) CN & $8.1-13.3$ & 44.5 & 44.4 & 38.8 & 36.7 & 34.6 \\
\hline
\end{tabular}




\section{Mass balance calculations}

The iso-element mass balance equation (Formula 3) as given by Nesbitt, 1979 was used to quantify the element transfer during weathering.

$$
\tau=\left[\left(C_{\text {e.w }} / C_{\text {i.w }}\right) /\left(C_{\text {e.pr }} / C_{\text {i.pr }}\right)\right]-1 \times 100 \%
$$

where $\tau$ is percentage change of the element ( $\%$ change), $C_{e, w}$ and $C_{i, w}$ are the concentration of the element in the weathered zone and the concentration of the iso-element in the weathered zone respectively, $C_{\text {e.pr, }}$ and $C_{\text {i.pr }}$ are the concentration of the element in the parent carbonatite and concentration of the iso-element in the parent carbonatite. Elemental gains will yield $\tau$ values higher than zero while $\tau$ values less than zero are considered as elemental losses. Values of $\tau$ equal to zero indicate neither gain nor loss of the given element.

Based on the data availability, Ti was used as the isoelement for calculations and the elemental compositions of the parent carbonatite were taken from geochemical data reported by previous research groups (Manthilake et al., 2008; Pitawala et al., 2003). The findings of this study can be utilized to evaluate the elemental transfer intensities analogous to the depth of the weathering crust, which have not been discussed in the previous studies. Variations of the $\%$ change $(\tau)$ of 10 elements with respect to the depth of the weathering profile were depicted in Figure 9.

The elements $\mathrm{Mg}, \mathrm{Ca}, \mathrm{Sr}, \mathrm{Na}, \mathrm{Ba}$ and $\mathrm{Mn}$ have been lost from the system while $\mathrm{P}$ and $\mathrm{Al}$ have been enriched during weathering of parent rock. Elements $\mathrm{Fe}$ and $\mathrm{Si}$ indicate both mass losses and gains upon weathering.

Despite the fact that the weathered profile is enriched with $\mathrm{P}$, decreasing pattern of accumulation intensity was observed upwards the profile's surface [Figure 9(a)]. The $\mathrm{P}$ gains are well correlated with the accumulation of primary apatite and the formation of various secondary phosphate products at the intermediate and lower layers of the weathering profile, as per the XRD results. However, intense weathering conditions prevailing in the uppermost layers have broken-down and leached out the phosphate material yielding elemental losses. Furthermore, Fe shows elemental gains in the upper layers of the alloteritic-saprolite zone due to the presence of residual primary iron phases and formation of secondary iron oxy-hydroxides. However, iron complexes from the upper layer of the profile have been removed under continuous weathering and leaching. Since the phosphates and iron oxy-hydroxides act as REEs carriers, the mass changes of $\mathrm{P}$ and $\mathrm{Fe}$ influence the distribution of REEs throughout the profile (Feitosa et al, 2020).

Interestingly, the ES profile indicates extremely higher mass gains for element $\mathrm{Al}$ showing a higher accumulation of $\mathrm{Al}$ compounds in the weathered profile. For $\mathrm{Si}$, mass losses were reported for the samples collected from the higher alloteritic-saprolite zone and lower levels of the leached zone. However, contrasting with the available literature indicating only losses for $\mathrm{Si}$ (Hewawasam, 2013), samples collected from the upper levels of the profile indicated positive values with an increasing trend towards the surface. These results suggest that one or more processes have influenced the silicate and alumina entering to the weathering system upon the formation of the profile.

Moreover, the mass transfer patterns depicted in the Figure 9 indicate similarities in $\mathrm{P}, \mathrm{Ca}$ and Fe elements. Hence, the matrices of the apatite enriched zones are also rich with Fe bearing phases which can influence the grade of the fertilizer raw material.

\section{Economic potential of the phosphate ore body}

The primary apatite crystals in the ores are free from toxic elements and can be used for the production of phosphate fertilizers (Dahanayake and Subasinghe, 1991). However, the findings of this study indicate that the matrix used for the Eppawala Rock Phosphate (ERP) is rich in $\mathrm{Fe}_{2} \mathrm{O}_{3}$ and (a)

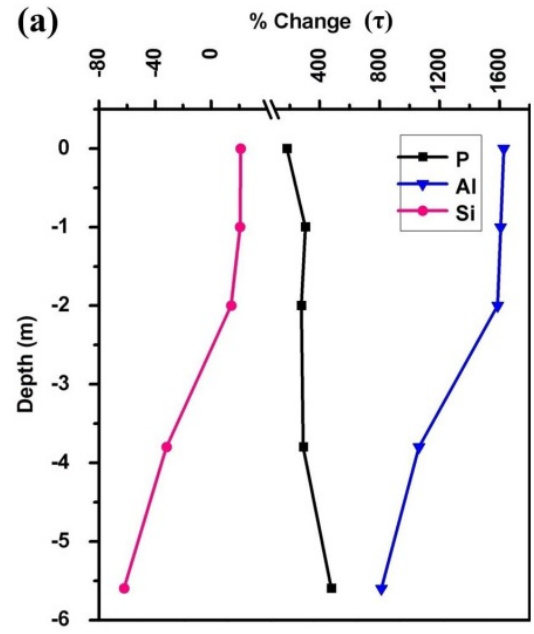

(b)

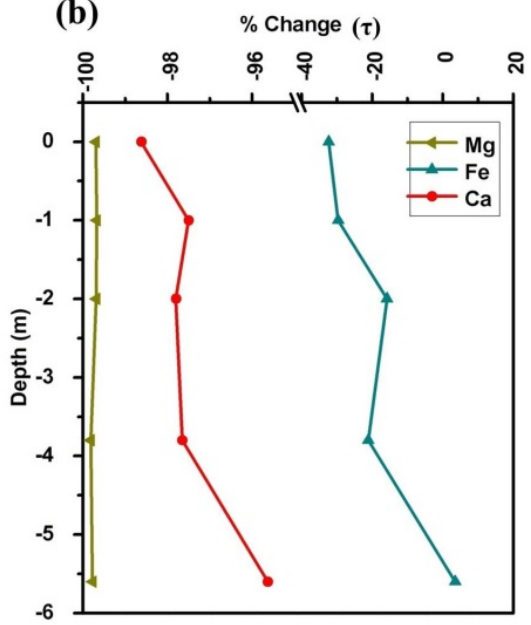

(c)

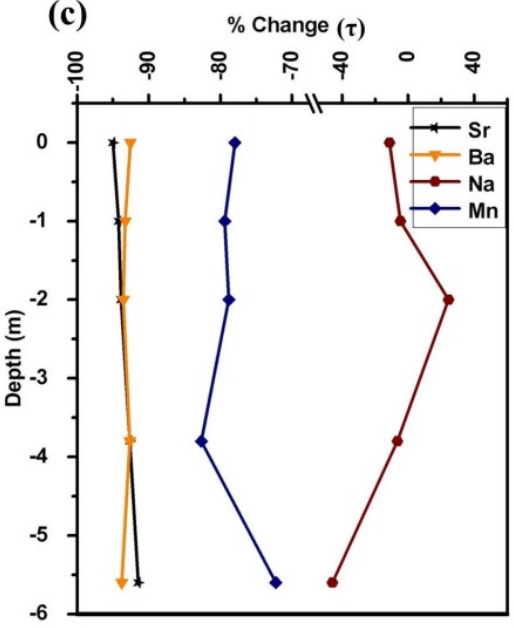

Figure 9: Depth profiles of the ES showing \% changes ( $\tau$ ); (a) and (b) Major elements (c) Minor and trace elements. Negative values of the $\%$ change showing elemental losses and positive values indicating elemental gains. 
$\mathrm{Al}_{2} \mathrm{O}_{3}$ The $\mathrm{R}_{2} \mathrm{O}_{3}\left(\mathrm{Fe}_{2} \mathrm{O}_{3}+\mathrm{Al}_{2} \mathrm{O}_{3}\right)$ concentration of the matrix exceeds the possible maximum level $(5 \%)$ recommended for the fertilizer product (Dwivedi and Gupta, 2006). High levels of $\mathrm{Fe}_{2} \mathrm{O}_{3}$ can be toxic to plants. As a consequence, the matrix is not suitable for the fertilizer industry. Hence, a proper screening process is required to be done to remove the toxic fraction containing $\mathrm{Fe}_{2} \mathrm{O}_{3}$ and $\mathrm{Al}_{2} \mathrm{O}_{3}$ if the secondary phosphate matrix is used for the production of fertilizers (Weerasooriya et al., 2018; Mata et al., 2020).

\section{CONCLUSION}

The profiles located in minimally karstified areas at the ES site exhibit distinguishable weathering zonations. The mineralization of various supergene phases accommodating REEs provides the hue of valuable industrial potential from the phosphate ore, except for the phosphate. However, further studies are essential to evaluate the economic feasibility of REEs by analyzing several samples covering whole deposits. The presence of secondary alumino-silicate minerals in phosphate ore that are not found in the main quarry site, as well as elevated amounts of $\mathrm{Al}_{2} \mathrm{O}_{3}$ and $\mathrm{SiO}_{2}$, indicate that country rock had intermingled with the parent carbonatites during the weathering processes.

A proper screening process for the phosphate matrices is recommended for selective removal of toxic fractions comprising $\mathrm{Fe}_{2} \mathrm{O}_{3}$ and $\mathrm{Al}_{2} \mathrm{O}_{3}$, which can deteriorate the quality of the raw material used for phosphate fertilizers. Mineralogy and the geochemistry of secondary products inherited from weathering of carbonatite can be applied as a tool for economic mining and beneficiation of phosphate ores.

\section{ACKNOWLEDGEMENT}

The authors wish to acknowledge the financial support provided by the Accelerating Higher Education Expansion and Development $(A H E A D)$ project by the World Bank (Grant No: AHEAD/RA3/ICE/PDN/SCI/Activity 4).

\section{DECLARATION OF CONFLICT OF INTEREST}

The authors declare no conflict of interest.

\section{DATA AVAILABILITY}

All relevant data are available on request from the corresponding author.

\section{REFERENCES}

Abd El Aal, A. (2017). Identification and characterization of near surface cavities in Tuwaiq Mountain Limestone, Riyadh, KSA, "detection and treatment." Egyptian Journal of Petroleum, 26(1):215-223. DOI: https://doi. org/10.1016/j.ejpe.2016.04.004.

Anenburg, M., Burnham, A. D., and Mavrogenes, J. A. (2018). Ree redistribution textures in altered fluorapatite: Symplectites, veins, and phosphatesilicate-carbonate assemblages from the nolans bore p-ree-th deposit, Northern Territory, Australia. Canadian Mineralogist, 56(3):331-354. DOI: https:// doi.org/10.3749/canmin.1700038.

Bhattacharyya, T., Pal, D. K. and Srivastava, P. (2000). Formation of gibbsite in the presence of 2:1 minerals: an example from Ultisols of northeast India. Clay Minerals, 35(5): 827-840. DOI: https://doi. org/10.1180/000985500547269.

Black, J. R., Carroll, S. A.and Haese, R. R. (2015). Rates of mineral dissolution under $\mathrm{CO} 2$ storage conditions. Chemical Geology, 399: 134-144. DOI: https://doi. org/10.1016/j.chemgeo.2014.09.020.

Broom-Fendley, S., Siegfried, P. R., Wall, F., O'Neill, M., Brooker, R. A., Fallon, E. K. and Banks, D. A. (2021). The origin and composition of carbonatitederived carbonate-bearing fluorapatite deposits. Mineralium Deposita, 56(5): 863-884. DOI: https:// doi.org/10.1007/s00126-020-01010-7.

Chen, W., Honghui, H., Bai, T. and Jiang, S. (2017). Geochemistry of Monazite within Carbonatite Related REE Deposits. Resources, 6(4): 51. DOI: https://doi. org/10.3390/resources6040051.

Churchman, G. J., Lowe, D. J. and Zealand, N. (2012). Alteration, formation, and occurrence of minerals in soils. In M. E. Huang, P.M.; Li, Y; Sumner (Ed.), Handbook of Soil Sciences. 2nd edition. (Vol. 1, pp. 20.1-20.72). Boca Raton, FL: CRC Press (Taylor \& Francis).

Cooray, P. G. (1994). The precambrian of Sri Lanka: a historical review. Precambrian Research, 66(1-4):3-18. DOI: https://doi.org/10.1016/0301-9268(94)90041-8

Dahanayake, K. and Subasinghe, S. M. N. D. (1991). Mineralogical, chemical and solubility variations in the Eppawala phosphate deposit of Sri Lanka - a case for selective mining for fertilizers. Fertilizer Research, 28(2): 233-238. DOI: https://doi.org/10.1007/ BF01049756.

Decree, S., Boulvais, P., Tack, L., Andre, L. and Baele, J. M. (2016). Fluorapatite in carbonatite-related phosphate deposits: the case of the Matongo carbonatite (Burundi). Mineralium Deposita, 51(4): 453-466. DOI: https://doi.org/10.1007/s00126-015-0620-1.

Dwivedi, A. D. and Gupta, D. K. (2006). Calcined Phosphate Fertilizer from Jhamarkotra Secondary Phosphate Ore and Rock Phosphate Beneficiation Plant Bulk Circuit Tail. In Proceedings of the International Seminar on Mineral Processing Technology - 2006 (pp. 382-389). Chennai, India.

Erdosh, G. (1979). The Ontario carbonatite province and its phosphate potential. Economic Geology, 74(2): 331338. DOI: https://doi.org/10.2113/gsecongeo.74.2.331.

Feitosa, M. M., da Silva, Y. J. A. B., Biondi, C. M., Alcantara, V. C. and do Nascimento, C. W. A. (2020). Rare Earth elements in rocks and soil profiles of a tropical volcanic archipelago in the Southern Atlantic. Catena, 194(March): 104674. DOI: https://doi. org/10.1016/j.catena.2020.104674.

Flicoteaux, R. and Lucas, J. (1984). Weathering of phosphate minerals. Phosphate Minerals, 3(Fisher 1973), 292-317. DOI: https://doi.org/10.1007/978-3642-61736-2 9.

Gu, X., Rempe, D. M., Dietrich, W. E., West, A. J., Lin, 
T. C., Jin, L. and Brantley, S. L. (2020). Chemical reactions, porosity, and microfracturing in shale during weathering: The effect of erosion rate. Geochimica et Cosmochimica Acta, 269: 63-100. DOI: https://doi. org/10.1016/j.gca.2019.09.044.

He, Y. T. and Traina, S. J. (2007). Transformation of magnetite to goethite under alkaline $\mathrm{pH}$ conditions. Clay Minerals, 42(1): 13-19. DOI: https://doi.org/10.1180/ claymin.2007.042.1.02.

Hewawasam, T. (2013). Tropical weathering of apatitebearing rocks of Sri Lanka: Major element behavior and mineralogical changes. Journal of Geological Society of Sri Lanka, 15: 31-46.

Janots, E., Bernier, F., Brunet, F., Muñoz, M., Trcera, N., Berger, A. and Lanson, M. (2015). Ce(III) and Ce(IV) (re)distribution and fractionation in a laterite profile from Madagascar: Insights from in situ XANES spectroscopy at the Ce LIII-edge. Geochimica et Cosmochimica Acta, 153: 134-148. DOI: https://doi. org/10.1016/j.gca.2015.01.009.

Jones, J. M. C., Guinel, F. C. and Antunes, P. M. (2020). Carbonatites as rock fertilizers: A review. Rhizosphere, 13. DOI: https://doi.org/10.1016/j.rhisph.2020.100188.

Joosu, L., Lepland, A., Kirsimäe, K., Romashkin, A. E., Roberts, N. M. W., Martin, A. P. and Crne, A. E. (2015). The REE-composition and petrography of apatite in $2 \mathrm{Ga}$ Zaonega Formation, Russia: The environmental setting for phosphogenesis. Chemical Geology, 395: 88-107. DOI: https://doi.org/10.1016/j.chemgeo.2014.11.013.

Le Bas, M. J. (1981). Carbonatite magmas. Mineralogical Magazine, 44(334): 133-140. DOI: https://doi. org/10.1180/minmag.1981.044.334.02.

Lerman, A. and Mackenzie, F. T. (2018). Carbonate minerals and the $\mathrm{CO}_{2}$-carbonic acid system. Encyclopedia of Earth Sciences Series, (January 2016), 206-226. DOI: https://doi.org/10.1007/978-3-319-39312-4_84.

Leroy, N., Bres, E., Jones, D. B. and Downes, S. (2001). Structure and substitutions in fluorapatite. European Cells and Materials, 2(33): 36-48. DOI: https://doi. org/10.22203/eCM.v002a05.

Ling, S., Wu, X., Ren, Y., Sun, C., Liao, X., Li, X. and Zhu, B. (2015). Geochemistry of trace and rare earth elements during weathering of black shale profiles in Northeast Chongqing, Southwestern China: Their mobilization, redistribution, and fractionation. Chemie Der Erde, 75(3): 403-417. DOI: https://doi. org/10.1016/j.chemer.2015.07.004.

Lottermoser, B. G. (1990). Rare-earth element mineralisation within the Mt. Weld carbonatite laterite, Western Australia. Lithos, 24(2): 151-167. DOI: https:// doi.org/10.1016/0024-4937(90)90022-S.

Luquot, L. and Gouze, P. (2009). Experimental determination of porosity and permeability changes induced by injection of $\mathrm{CO} 2$ into carbonate rocks. Chemical Geology, 265(1-2): 148-159. DOI: https:// doi.org/10.1016/j.chemgeo.2009.03.028.

Madugalla, N. S., Pitawala, A. and Manthilake, G. (2017). Primary and secondary textures of dolomite in Eppawala carbonatites, Sri Lanka: Implications for their petrogenetic history. Journal of Geosciences
(Czech Republic), 62(3): 187-200. DOI: https://doi. org/10.3190/jgeosci.242.

Manthilake, M. A. G. M., Sawada, Y. and Sakai, S. (2008). Genesis and evolution of Eppawala carbonatites, Sri Lanka. Journal of Asian Earth Sciences, 32(1): 66-75. DOI: https://doi.org/10.1016/j.jseaes.2007.10.015.

Martin, J. B. (2017). Carbonate minerals in the global carbon cycle. Chemical Geology, 449, 58-72. DOI: https://doi.org/10.1016/j.chemgeo.2016.11.029.

Mitchell, R. H. (2005). Carbonatites and carbonatites and carbonatites. Canadian Mineralogist, 43(6): 20492068. DOI: https://doi.org/10.2113/gscanmin.43.6.2049

Nasraoui, M., Toulkeridis, T., Clauer, N. and Bilal, E. (2000). Differentiated hydrothermal and meteoric alterations of the Lueshe carbonatite complex (Democratic Republic of Congo) identified by a REE study combined with a sequential acid-leaching experiment. Chemical Geology, 165(1-2): 109-132. DOI: https://doi.org/10.1016/S0009-2541(99)00165-5.

Nesbitt, H. W. (1979). Mobility and fractionation of rare earth elements during weathering of a granodiorite. Nature, 279(5710): 206-210. DOI: https://doi. org/10.1038/279206a0.

Pitawala, A. and Lottermoser, B. G. (2012). Petrogenesis of the Eppawala carbonatites, Sri Lanka: A cathodoluminescence and electron microprobe study. Mineralogy and Petrology, 105(1-2): 57-70. DOI: https://doi.org/10.1007/s00710-012-0193-y.

Pitawala, A., Schidlowski, M., Dahanayake, K. and Hofmeister, W. (2003). Geochemical and petrological characteristics of Eppawala phosphate deposits, Sri Lanka. Mineralium Deposita, 38(4): 505-515. DOI: https://doi.org/10.1007/s00126-002-0327-y.

Reynard, B., Lécuyer, C. and Grandjean, P. (1999). Crystal-chemical controls on rare-earth element concentrations in fossil biogenic apatites and implications for paleoenvironmental reconstructions. Chemical Geology, 155(3-4): 233-241. DOI: https:// doi.org/10.1016/S0009-2541(98)00169-7.

Roseiro, J., Ribeiro da Costa, I., Figueiras, J., Rodrigues, P. and Mateus, A. (2020). Nb-bearing mineral phases in the bailundo carbonatite complex (Angola): Implications of $\mathrm{nb}$ geochemistry in metallogenesis. Comunicacoes Geologicas, 107(Special Issue 2): 75-80.

Tacker, R. C. (2008). Carbonate in igneous and metamorphic fluorapatite: Two type A and two type B substitutions. American Mineralogist, 93(1): 168-176. DOI: https:// doi.org/10.2138/am.2008.2551.

Van Gosen, B. S., Verplanck, P. L., Seal II, R. R., Long, K. R. and Gambogi, J. (2017). Rare-Earth Elements. In Klaus J. Schulz, ohn H. DeYoung, R. R. Seal, and D. C. Bradley (Eds.), Critical Mineral Resources of the United States-Economic and Environmental Geology and Prospects for Future Supply (pp. O1- O31). U.S. Geological Survey. DOI: https://doi.org/https://doi. org/10.3133/pp1802O.

Vieillard, P., Tardy, Y. and Nahon, D. (1979). Stability fields of clays and aluminum phosphates: Parageneses in lateritic weathering of argillaceous phosphatic sediments. American Mineralogist, 64(5-6 PART1), 626-634. 
Walter, A., Nahon, D., Flicoteaux, R., Girard, J. P. and Melfi, A. (1995). Behaviour of major and trace elements and fractionation of REE under tropical weathering of a typical apatite-rich carbonatite from. Earth and Planetary Science Letters, 136, 591-602.

Witt, W. K., Hammond, D. P. and Hughes, M. (2019). Geology of the Ngualla carbonatite complex, Tanzania, and origin of the Weathered Bastnaesite Zone REE ore. Ore Geology Reviews, 105, 28-54. DOI: https://doi. org/10.1016/j.oregeorev.2018.12.002.

Zhao, C., Hobbs, B. E. and Ord, A. (2013). Theoretical analyses of acidization dissolution front instability in fluid-saturated carbonate rocks. International Journal for Numerical and Analytical Methods in Geomechanics, 37(13), 2084-2105. DOI: https://doi. org/10.1002/nag.2123. 